\title{
Seed Cryostorage and Micropropagation of Georgia Aster, Symphyotrichum georgianum (Alexander) Nesom: A Threatened Species from the Southeastern United States
}

\author{
Sullivan Lynch and Rachel K. Johnston \\ School of Biology, Georgia Institute of Technology, 310 Ferst Drive, Atlanta, \\ GA 30332
}

\author{
Ron O. Determann and Jennifer M. Cruse-Sanders \\ Department of Conservation Research, Atlanta Botanical Garden, 1345 \\ Piedmont Avenue, NE, Atlanta, GA 30309
}

Gerald S. Pullman ${ }^{1}$

School of Biology, Georgia Institute of Technology, Atlanta, GA 30332; and the Institute of Paper Science and Technology, Georgia Institute of Technology, 500 10th Street NW, Atlanta, GA 30332-0620 Additional index words. conservation, cryopreservation, endangered species, Georgia aster,
micropropagation, Symphyotrichum georgianum

\begin{abstract}
Symphyotrichum georgianum (Asteraceae), commonly known as Georgia aster, is a candidate for listing under the Federal Endangered Species Act in the four southeastern U.S. states where it lives. Rarity of this species is thought to be attributable in part to small population sizes and limited seed production. Protocols for in vitro germination, sustainable shoot micropropagation, shoot establishment in soil, and seed cryopreservation are presented that will assist in the safeguarding and augmentation of dwindling natural populations. Germination in vitro on growth regulator-free half-strength Murashige and Skoog (MS) medium after sterilization in $\mathrm{H}_{2} \mathrm{O}_{2}$ initiated the development of shoot cultures. Shoot multiplication and elongation occurred on half-strength MS salts containing $0.1 \mathrm{mg} \cdot \mathrm{L}^{-1}$ benzylaminopurine and $0.2 \mathrm{mg} \cdot \mathrm{L}^{-1}$ gibberellic acid, producing an average of 18 new shoots over a 6- to 8-week subculture cycle. Shoots rooted easily when planted into cutting mix after treatment with rooting powder containing indole-3-butyric acid (IBA) or in vitro rooting in medium with or without $\mathrm{N}$-acetyl-L-aspartic acid (NAA). Plant survival after 1 month was $\mathbf{9 0 \%}$ or higher for all treatments. Cryopreservation tests with seeds from three populations averaged $46.7 \%$ germination compared with control seed (no cryostorage) germination of $\mathbf{4 3 \%}$; differences were not statistically significant. Fresh seeds and seeds equilibrated for 1 to 4 weeks at room temperature and $12 \%$ relative humidity did not differ significantly in germination post-cryopreservation. Initial observations suggest that Georgia aster rapidly loses seed viability over 1 to 2 years when stored at room temperature. The ability to increase seed longevity through cryopreservation storage may be a critical step in the conservation of this species.
\end{abstract}

Symphyotrichum georgianum (Alexander) Nesom (syn. Aster georgianus), commonly known as Georgia aster, is a perennial member

\footnotetext{
Received for publication 20 Mar. 2013. Accepted for publication 3 Apr. 2013.

We thank Allyson Reed, Joanne Baggs, and Robyn Mackie for help in obtaining Georgia aster seed and gratefully acknowledge the help of Kylie Bucalo, Maria Dinh, Dionne Wells, and Kathryn Wright. We thank the Georgia Institute of Technology for providing a Materials, Supplies and Travel Grant for Undergraduate Research in support of this project and the USDA Forest Service for partial funding of the study. Seed was obtained under National Park Service permit \# KIMO-2011-SCI-003.

${ }^{1}$ To whom reprint requests should be addressed; e-mail Jerry.Pullman@ipst.gatech.edu.
}

extirpated. Extant populations typically have 10 to 500 stems often containing only one or a few genotypes (Federal Register, 2009; USFWS, 2010).

Georgia aster grows up to $100 \mathrm{~cm}$ in height and flowers in early October to midNovember with 5-cm diameter heads having dark purple rays surrounding white (occasionally purple) disc flowers with purplish tips, purplish anthers, and whitish pollen (Chafin, 2007; Georgia Department of Natural Resources Wildlife Resources Division, 2008; Weakley, 2011). Successful pollination results in the production of achene-like fruits (cypselae) that each contain a single seed and embryo. However, the species reproduces mostly asexually from rhizomes (USFWS, 2010). The habitat it now most often occupies include roadsides, utility rightsof-way, and openings where land management mimics the roles formerly played by fire and a dry upland habitat. Unfortunately, these areas also leave Georgia aster at risk to invasive species such as kudzu, herbicides, road expansion, and development. Herbicide use can further fragment populations, potentially reducing population persistence and survival in small isolated patches.

In vitro propagation from seed, shoot tips, and rhizomes can multiply the number of individuals of an endangered species rapidly and continually (Fay, 1992; Reed et al., 2011). Once enough plants are available, they can be used to repopulate old populations or to establish new populations for conservation, research, education, or recreational purposes.

Cryopreservation is emerging as a reliable process for seed conservation and long-term storage of many desiccation-tolerant seeds and is likely to maintain seed viability for longer periods than conventional storage at $-18{ }^{\circ} \mathrm{C}$ (Englemann, 2011; Li and Pritchard, 2009; Pritchard, 2007; Reed et al., 2011). Seed cryopreservation may play a particularly important role in the conservation of threatened plants because safeguarding or propagating material from seed maintains new genetic combinations resulting from sexual reproduction (Pence, 1991).

The objectives of this study were to develop a reliable micropropagation protocol for threatened Georgia aster using seeds to start cultures and to investigate the feasibility of long-term seed storage through cryopreservation.

\section{Materials and Methods} is now classified as a vulnerable species with a moderate and imminent threat of extinction (Federal Register, 2009; USFWS, 2010). The species is currently found in south-central North Carolina, South Carolina to central Georgia, west to central Alabama, and on the Coastal Plain of southwest Georgia. There are 127 known populations, many of which have not been seen in 10 years and 23 of which have been either extirpated or not observed for over 20 years (USFWS, 2010; Weakley, 2011). Historic populations in the eastern Panhandle of Florida are considered
Plant materials, experimental design, and evaluation

A small number of $S$. georgianum seeds collected in Nov. 2009 from two locations designated as CP and PM in Cobb County, $\mathrm{GA}$, were stored at 22 to $25^{\circ} \mathrm{C}$ until germination tests occurred in 2010 . Seeds were also collected in Dec. 2010 from three Union County, SC, sites (SC5, SC7, SC8), stored at 22 to $25{ }^{\circ} \mathrm{C}$, and used during winter and Spring 2011. 


\section{Georgia aster seed sterilization and} germination in vitro and after storage

Preliminary experiments with small numbers of 2009 CP and PM seeds indicated that germination occurred on one-third strength MS salts (Murashige and Skoog, 1962), the large seed pappus did not need to be removed during seed sterilization, filled seed should be selected using a strong light behind the seeds, and stronger sterilization than $10 \mathrm{~min}$ in $20 \%$ $\mathrm{H}_{2} \mathrm{O}_{2}$ (Pullman et al., 2005, 2006) was needed.

Germination and sterilization. Year 2009 seeds were examined with a strong light, and empty seeds were discarded (Fig. 1A). To reduce seed surface fungal and bacteria contamination seen in preliminary experiments, full seeds with attached pappus were split into two treatments, and sterilization in $20 \% \mathrm{H}_{2} \mathrm{O}_{2}$ for 10 or 15 min was compared. Seeds were washed in running cold tap water for $10 \mathrm{~min}$, washed with a solution of $10 \%$ Liqui-Nox and $0.2 \%$ Tween 20 for $10 \mathrm{~min}$, rinsed in running cold tap water for $30 \mathrm{~min}$, and then surfacesterilized aseptically in $20 \% \mathrm{H}_{2} \mathrm{O}_{2}$ for 10 or 15 min with continuous stirring. Seeds were then rinsed five times with sterile deionized water (Pullman et al., 2005, 2006). Seed numbers used from the two collections (CP and $\mathrm{PM}$ ) were 18 and 10, respectively, for each treatment. Seeds were placed individually onto $7 \mathrm{~mL}$ of semisolid one-third-strength MS salts along with $3 \%$ sucrose, $100 \mathrm{mg} \cdot \mathrm{L}^{-1}$ myo-inositol, $0.33 \mathrm{mg} \cdot \mathrm{L}^{-1}$ thiamine $\mathrm{HCl}$, $0.165 \mathrm{mg} \cdot \mathrm{L}^{-1}$ pyridoxine $\mathrm{HCl}, 0.165 \mathrm{mg} \cdot \mathrm{L}^{-1}$ nicotinic acid, $0.66 \mathrm{mg} \cdot \mathrm{L}^{-1}$ glycine, and $4.5 \mathrm{~g} \cdot \mathrm{L}^{-1}$ Phytagel. Medium $\mathrm{pH}$ was adjusted with $\mathrm{KOH}$ or $\mathrm{HCl}$ to 5.7 after addition of all ingredients except gelling agent and autoclaved at $121^{\circ} \mathrm{C}$ for $20 \mathrm{~min}$. Seeds were incubated on medium in $60 \times 15-\mathrm{mm}$ petri
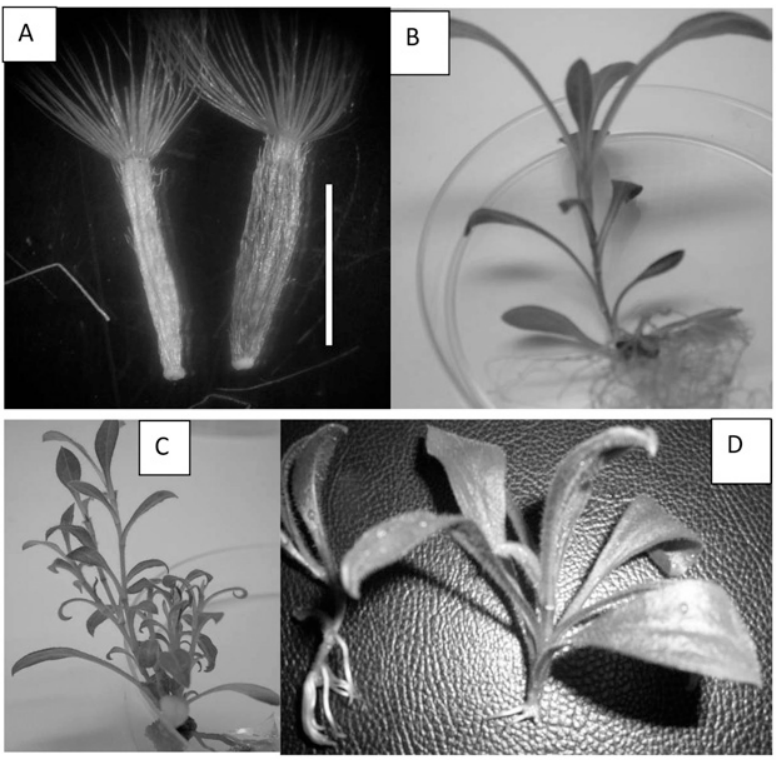

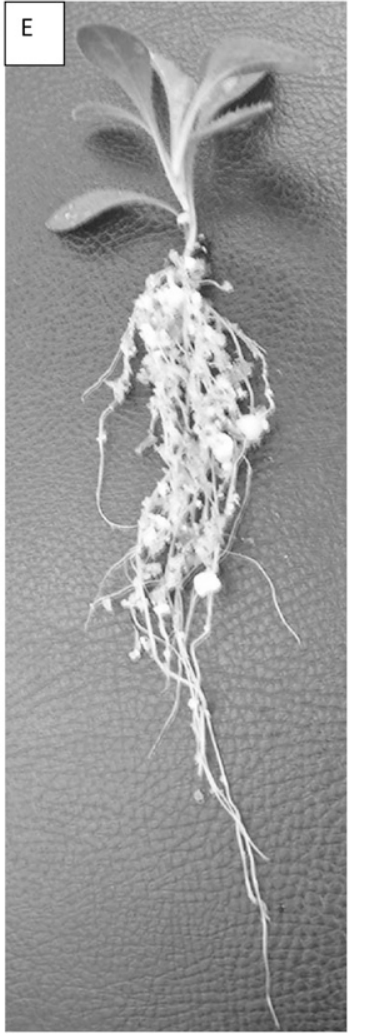

Fig. 1. Symphyotrichum georgianum: (A) Cypsela (fruit containing a seed) showing the large pappus appendage presumed to aid in dispersal. Two seeds are examined with strong light. Cypsela on the left is empty; the one on the right is filled. (B) Seedling growing on growth regulator-free half-strength Murashige and Skoog (MS) medium. (C) Shoot culture forming a miniature hedge growing on multiplication medium containing half-strength $\mathrm{MS}$ salts with $0.1 \mathrm{mg} \cdot \mathrm{L}^{-1} \mathrm{BAP}$ and $0.2 \mathrm{mg} \cdot \mathrm{L}^{-1}$ gibberellic acid. (D) Shoots cut from multiplication medium and rooted in vitro for $10 \mathrm{~d}$ in half-strength MS salts with $0.1 \mathrm{mg} \cdot \mathrm{L}^{-1} \mathrm{NAA}$ (left) or without growth regulators (right). (E) Rooted shoot 1 month after rooting hormone treatment and planting in cutting mix. Scale bar $=0.5 \mathrm{~cm}$. BAP= benzylaminopurine; NAA $=\mathrm{N}$-acetyl-L-aspartic acid.

Table 1. Georgia aster seed germination in vitro on one-third-strength Murashige and Skoog medium after surface sterilization treatments with $20 \%$ hydrogen peroxide.

\begin{tabular}{lcccrr}
\hline Seed lot & Sterilization time $(\mathrm{min})$ & No. of seeds & No. contaminated & No. clean & No. germinated \\
\hline CP & 10 & 18 & $0\left(0 \%^{\mathrm{z}}\right)$ & 18 & $15(83 \%)$ \\
PM & 10 & 10 & $2(20 \%)$ & 8 & $3(38 \%)$ \\
CP & 15 & 17 & $0(0 \%)$ & 17 & $15(88 \%)$ \\
PM & 15 & 10 & $0(0 \%)$ & 10 & $3(30 \%)$ \\
\hline
\end{tabular}

${ }^{\mathrm{z}}$ Germination percentages are based on germination of clean seed. plates and kept at 25 to $26^{\circ} \mathrm{C}$ under a $16 / 8$-h (day/night) photoperiod with light from cool white fluorescent lamps at $\approx 30 \mu \mathrm{mol} \cdot \mathrm{m}^{-2} \cdot \mathrm{s}^{-1}$. Germination responses were evaluated at 3 weeks.

Storage. To test seed viability after longterm storage, 38 filled seeds from CP collected in Nov. 2009 and stored in a plastic bag at $4{ }^{\circ} \mathrm{C}$ for 2 years and 30 filled seeds from SC8 collected in Dec. 2010 and stored in a plastic bag at 22 to $25^{\circ} \mathrm{C}$ for 1 year were tested for germination after surface sterilization in $20 \% \mathrm{H}_{2} \mathrm{O}_{2}$ for 15 min and 3 weeks on growth regulator-free half-strength MS salts with $3 \%$ sucrose, $100 \mathrm{mg} \cdot \mathrm{L}^{-1}$ myo-inositol, $0.495 \mathrm{mg} \cdot \mathrm{L}^{-1}$ thiamine $\mathrm{HCl}, 0.248 \mathrm{mg} \cdot \mathrm{L}^{-1}$ pyridoxine $\mathrm{HCl}, 0.248 \mathrm{mg} \cdot \mathrm{L}^{-1}$ nicotinic acid, $0.99 \mathrm{mg} \cdot \mathrm{L}^{-1}$ glycine, and $4.5 \mathrm{~g} \cdot \mathrm{L}^{-1}$ Phytagel with $\mathrm{pH}$ adjusted to 5.7. Seeds from the same lots, 23 from $\mathrm{CP}$ and 58 from SC8, were tested for germination in vitro shortly after collection using the same methods.

\section{Georgia aster growth in vitro and shoot multiplication experiments}

Nutritional salts. To determine the optimal strength of MS salts, shoot growth was compared across one-third strength, halfstrength, and full-strength MS medium without growth regulators. Full-strength MS medium contained $3 \%$ sucrose, $100 \mathrm{mg} \cdot \mathrm{L}^{-1}$ myo-inositol, $1.0 \mathrm{mg} \cdot \mathrm{L}^{-1}$ thiamine $\mathrm{HCl}, 0.5$ $\mathrm{mg} \cdot \mathrm{L}^{-1}$ pyridoxine $\mathrm{HCl}, 0.5 \mathrm{mg} \cdot \mathrm{L}^{-1}$ nicotinic acid, $1.0 \mathrm{mg} \cdot \mathrm{L}^{-1}$ glycine, and $4.5 \mathrm{~g} \cdot \mathrm{L}^{-1}$ Phytagel. Shoots from 36 non-contaminated germinants of similar size (1 to $1.5 \mathrm{~cm}$ ) from previous sterilization and germination experiments were divided randomly among treatments. Roots were removed and shoots inserted $\approx 3$ to $4 \mathrm{~mm}$ vertically into $20 \mathrm{~mL}$ medium in Magenta boxes (Magenta, Chicago, IL). Shoot heights were measured after 2 and 6 weeks.

Plant growth regulators. Three experiments were done to identify optimal concentrations of plant growth regulators for shoot multiplication. Each replicate contained a germinant or shoot $3 \mathrm{~cm}$ or larger divided into a tip, nodal segment, and basal segment with roots removed and placed in a Magenta boxes with $20 \mathrm{~mL}$ of test medium. Boxes were wrapped in Parafilm and incubated for 6 to 8 weeks in the same lighted culture room used for in vitro germination. Shoots $1 \mathrm{~cm}$ or larger were counted at the end of the cycle, separated, and placed on fresh medium of the same content for a second subculture. The number of shoots per initial explant was compared for each medium by analysis of variance and multiple range tests.

The first trial for shoot multiplication combined half-strength MS medium with benzylaminopurine (BAP) alone or BAP and gibberellic acid $\left(\mathrm{GA}_{3}\right)$. Seven treatments shown as $\mathrm{mg} \cdot \mathrm{L}^{-1} \mathrm{BAP} / \mathrm{mg} \cdot \mathrm{L}^{-1} \mathrm{GA}_{3}$ : were as follows: $0 / 0,0.5 / 0,1.0 / 0,1.5 / 0,2.0 / 0,2.5 / 0$, and $1.0 / 0.2$. Each treatment was tested using three replicates grown for two 8-week subcultures.

The second trial contained 11 treatments to further optimize shoot production. Treatments 
contained half-strength MS medium with BAP (mg. $\left.\mathrm{L}^{-1}\right) / \mathrm{GA}_{3}\left(\mathrm{mg} \cdot \mathrm{L}^{-1}\right): 0 / 0,0.1 / 0,0.25 /$ $0,0.5 / 0,0 / 0.1,0 / 0.2,0 / 0.5,0 / 1.0,0.1 / 0.2$, $0.25 / 0.2$, and $0.5 / 0.2$. Four replicates were tested per treatment for 8 weeks.

A third trial varied $\mathrm{GA}_{3}$ levels with a fixed BAP amount and compared shoot production

Table 2. Georgia aster shoot growth after 6 weeks in medium varying in Murashige and Skoog (MS) salt strength.

\begin{tabular}{lcl}
\hline Medium & $\begin{array}{c}\text { No.\# of } \\
\text { shoots }\end{array}$ & $\begin{array}{c}\text { Shoot } \\
\text { ht }(\mathrm{cm})\end{array}$ \\
\hline One-third MS salts & 12 & $3.2 \mathrm{ab}^{\mathrm{z}}$ \\
Half-strength MS salts & 12 & $4.3 \mathrm{~b}$ \\
Full-strength MS salts & 12 & $2.0 \mathrm{a}$
\end{tabular}

${ }^{\mathrm{z}}$ Values within a treatment followed by the same letter are not statistically different by the multiple range test at $P<0.05$. from segmented shoots vs. basal clusters for five half-strength MS medium treatments: BAP (mg. $\left.\mathrm{L}^{-1}\right) / \mathrm{GA}_{3} \quad\left(\mathrm{mg} \cdot \mathrm{L}^{-1}\right) \quad 0 / 0,0.1 / 0.1$, $0.1 / 0.2,0.1 / 0.3$, and $0.1 / 0.5$. Four replicates were divided into shoot tips, nodal segments, and basal segments. Four more replicates contained shoot tips and undivided basal clusters. After 6 weeks, shoots $1 \mathrm{~cm}$ or larger were counted for each treatment and explant type.

\section{Georgia aster root induction in vitro and acclimation to soil}

Two trials were carried out to establish shoots in soil. In the first trial, shoots were grown on multiplication medium with halfstrength MS medium, $0.1 \mathrm{mg} \cdot \mathrm{L}^{-1} \mathrm{BAP}$, and $0.2 \mathrm{mg} \cdot \mathrm{L}^{-1} \mathrm{GA}_{3}$ for 8 weeks. In the second trial, shoots were grown on multiplication medium for 8 weeks followed by shoot
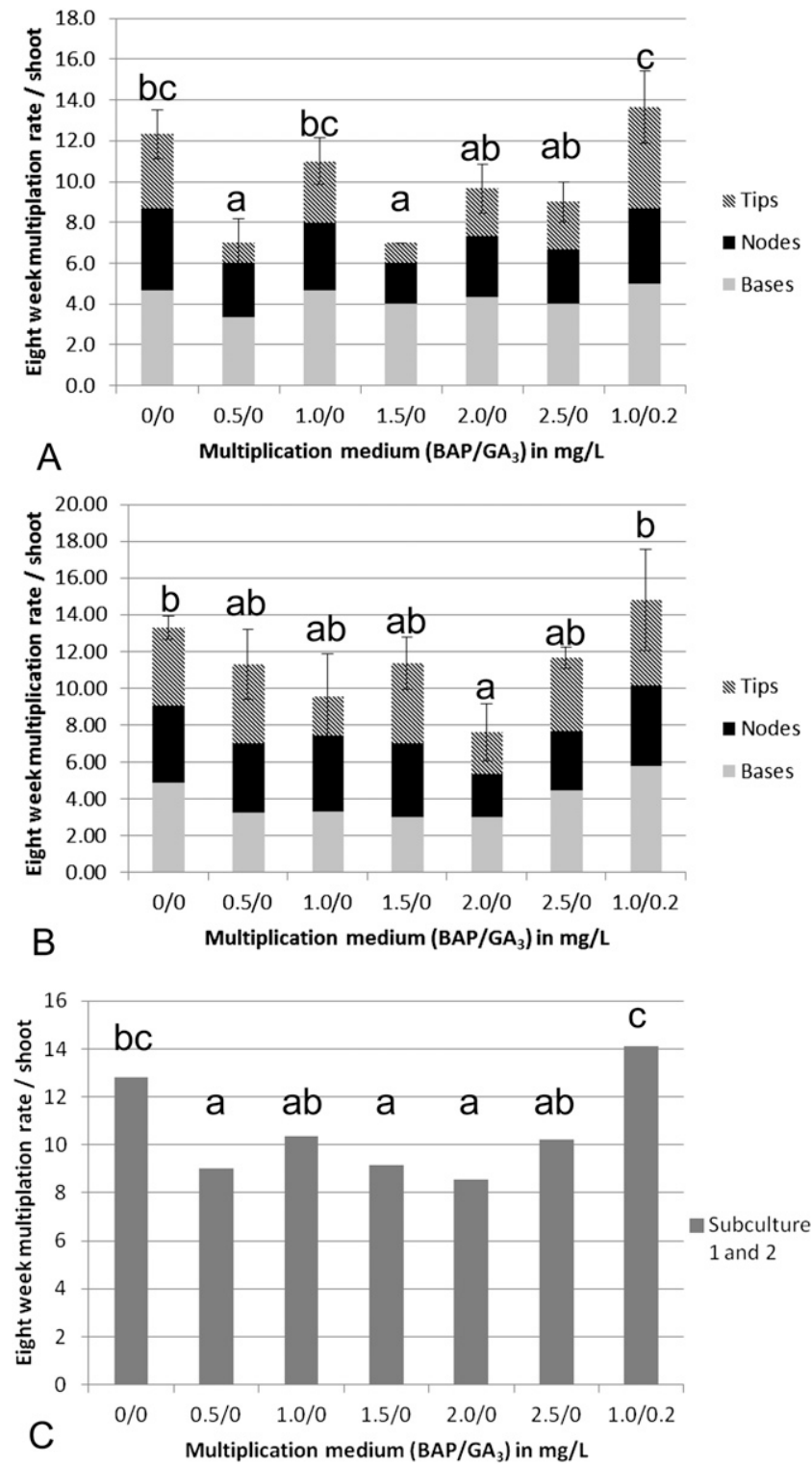

Fig. 2. Multiplication rates per shoot tip, segment, and base for each medium per 8-week interval. SES for total shoot production are shown for each treatment (bar). Bars for the same subculture or combined subcultures with the same letter are not statistically different by the multiple range test at $P=0.05$. (A) First subculture. (B) Second subculture. (C) Average of total shoots produced for both subcultures combined.

cluster growth on growth regulator-free halfstrength MS medium for 6 weeks to decrease residual plant growth regulators. Shoots 2 to $4 \mathrm{~cm}$ in size were isolated from the resulting shoot clusters and transferred to three treatments: 1) directly into cutting mix after dipping into Green Light Rooting Hormone containing $0.1 \%$ IBA (Green Light Company, Antonio, TX); 2) growth for 10 to $14 \mathrm{~d}$ in half-strength MS medium with no growth regulators and planting in cutting mix; or 3) growth for 10 to $14 \mathrm{~d}$ in halfstrength MS medium with $0.1 \mathrm{mg} \cdot \mathrm{L}^{-1} \mathrm{NAA}$ and planting in cutting mix. Both trials contained 30 shoots divided into three replications of 10 shoots. Rooting treatments in vitro occurred on $20 \mathrm{~mL}$ of medium in Magenta boxes incubated at 25 to $26{ }^{\circ} \mathrm{C}$ under the same lighting conditions previously described. When plants were removed from sterile culture, gelling agent was removed by rinsing with water. Shoots were placed $1 / 2 \mathrm{~cm}$ deep in Atlanta Botanical Garden cutting mix composed of one part milled New Zealand sphagnum moss : one part perlite : one part pumice. When roots were present, care was taken to decrease root damage during planting. Trays containing plants and cutting mix were watered daily, covered with transparent plastic domes, and placed in a greenhouse with natural light during the late fall and temperatures maintained above $18.3{ }^{\circ} \mathrm{C}$ at night and below $29.4{ }^{\circ} \mathrm{C}$ in the day. Plants were evaluated for survival after 2 weeks and 1 month.

\section{Georgia aster seed cryopreservation in liquid nitrogen}

S. georgianum seeds were collected from South Carolina in late fall and stored at room temperature in paper envelopes until tested for water content and cryopreservation tolerance in winter and spring. To determine seed water contents, 10 seed per seed lot were placed in small pre-weighed glass vials, covered with aluminum foil to prevent water exchange with the air, and weighed. Seed were dried for at least $24 \mathrm{~h}$ at $105^{\circ} \mathrm{C}$ in the uncovered vial and then covered, cooled to room temperature, and reweighed to obtain dry weights for water content calculations. As a result of the small number of seeds available, only one measurement was taken for each seed lot.

To determine if further drying at 22 to $25^{\circ} \mathrm{C}$ and low humidity affect survival after cryopreservation, seeds from several locations in South Carolina were divided into five sets and dried at 22 to $25^{\circ} \mathrm{C}$ for $0,1,2,3$, or 4 weeks over calcium sulfate desiccant at $12 \%$ relative humidity (Walls, 2009). After each drying period, half of the seeds were placed in Nalgene cryogenic vials and rapidly immersed in liquid nitrogen (LN) for at least $48 \mathrm{~h}$. Half of the seeds remained untreated. To retrieve seed, vials were removed from $\mathrm{LN}$ and thawed in a $37^{\circ} \mathrm{C}$ water bath for 1 to $2 \mathrm{~min}$. Seeds from control and cryopreserved treatments were surface-sterilized and tested for germination on growth regulator-free halfstrength MS medium for 4 weeks. 

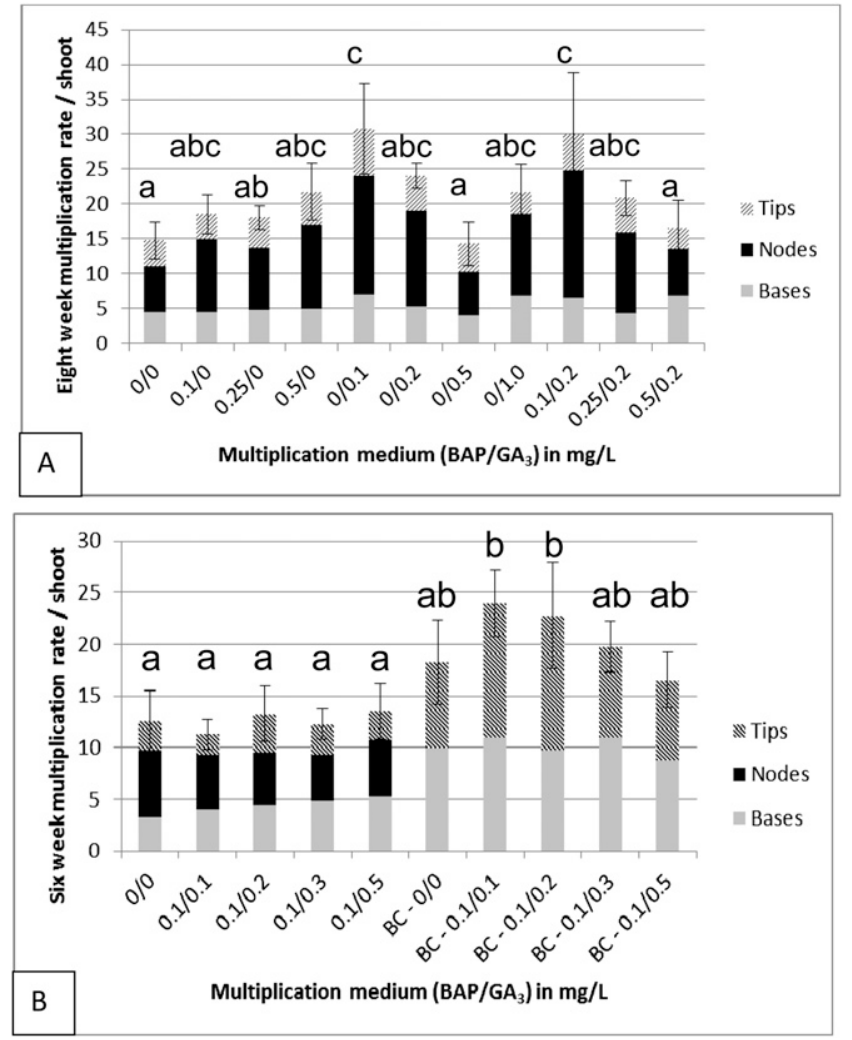

Fig. 3. (A) Trial 2. Multiplication rates per shoot tip, segments, and base for each treatment per 8-week interval. (B) Trial 3. First five treatments: multiplication rate per shoot tip, segment, and base at each medium concentration per 6-week interval. Second five treatments: multiplication rate per basal cluster and shoot tip. ses for total shoot production are shown for each treatment (bar). Bars with the same letter are not statistically different by the multiple range test at $P=0.05$.

Table 3. Georgia aster micropropagated shoot performance during rooting and acclimation in soil. ${ }^{\mathrm{z}}$

\begin{tabular}{lccc}
\hline Treatment & $\begin{array}{c}\text { Number (\%) of } \\
\text { shoots with roots in } \\
\text { vitro before planting }\end{array}$ & $\begin{array}{c}\text { Number (\%) } \\
\text { surviving } \\
\text { at 2 weeks }\end{array}$ & $\begin{array}{c}\text { Number (\%) } \\
\text { surviving } \\
\text { after 1 month }\end{array}$ \\
\hline $\begin{array}{l}\text { Shoots grown on multiplication medium followed by growth regulator-free medium } \\
\text { Planted directly into soil }\end{array}$ & $0(0)$ & $29(97)$ & $29(97) \mathrm{a}^{\mathrm{y}}$ \\
In vitro rooted with NAA & $17(57)$ & $28(93)$ & $27(90) \mathrm{a}$ \\
$\quad$ In vitro rooted no growth regulators & $26(87)$ & $30(100)$ & $30(100) \mathrm{a}$ \\
Shoots grown on multiplication medium & & $28(93)$ & $28(93) \mathrm{a}$ \\
$\quad$ Planted directly into soil & $0(0)$ & $30(100)$ & $30(100) \mathrm{a}$ \\
In vitro rooted with NAA & $23(77)$ & $30(100)$ & $30(100) \mathrm{a}$ \\
In vitro rooted no growth regulators & $25(83)$ &
\end{tabular}

${ }^{\mathrm{z}}$ All treatments consisted of 30 shoots.

${ }^{\mathrm{y}}$ Values within a treatment followed by the same letter are not statistically different by the multiple range test at $P<0.05$.

NAA $=$ N-acetyl-L-aspartic acid

\section{Results}

\section{Georgia aster seed sterilization and} germination in vitro and after storage

Germination and sterilization. Seeds began to germinate after 1 week and generally reached maximum germination by 3 weeks (data not shown). Seed contamination and germination are shown in Table 1 . Two of 28 seeds $(7.1 \%)$ subjected to the 10 -min sterilization became contaminated and none of the 27 seed treated for 15 min were contaminated. Across all seed lots, germination averaged $64 \%$ for 10 -min sterilization and $67 \%$ for 15-min sterilization treatments. As a result of decreased contamination and no negative effect on germination, 15-min sterilization treatments were used for later experiments.

Storage. Viability of SC8 seeds stored for 1 year at room temperature declined from $72 \%$ to $7 \%$. CP seeds stored at $4{ }^{\circ} \mathrm{C}$ for 2 years showed a less drastic decline, changing in viability from $91 \%$ to $66 \%$. Using Student's $t$ test, germination percentages differed significantly $(P=0.01)$ when compared with fresh seeds tested earlier for both seed lots.

\section{Georgia aster growth in vitro and shoot multiplication experiments}

Nutritional salts. Over 6 weeks shoots grew from starting sizes of 1 to $1.5 \mathrm{~cm}$ to 2 to
$4.3 \mathrm{~cm}$ (Fig. 1B). Growth differences occurred between salt concentrations with halfstrength MS showing the most growth and full-strength the least growth (Table 2). Differences in shoot height were statistically significant at $P=0.05$. Many of the resulting elongated shoots showed root development. Medium containing half-strength MS medium was used for further experiments.

Plant growth regulators. In Trial 1, after 2 weeks, nearly all shoots showed signs of growth. Shoot tips and bases in treatments containing BAP began to show axillary budbreak. At 3 weeks, axillary budbreaks were apparent on most base segments, nodal sections, and shoot tips. At 8 weeks, shoots $1 \mathrm{~cm}$ or larger resulting from bases, segments, and tips were counted and presented as totals (Fig. 2A-B). The treatments without growth regulators and with combined $\mathrm{BAP}$ and $\mathrm{GA}_{3}$ produced the most shoots. When data from the two subcultures were combined, shoot yields for treatments containing BAP and $\mathrm{GA}_{3}$ produced more shoots than most other treatments, and differences were often statistically significant (Fig. 2C). Addition of BAP to the basal medium reduced the number of elongated shoots for most treatments, but when $\mathrm{GA}_{3}$ was added, shoots elongated and production of shoots $1 \mathrm{~cm}$ or larger increased. Spontaneous rooting was often observed in multiplication or growth regulator-free medium.

In Trial 2, after 8 weeks, of the 11 plant growth regulator treatments tested, media containing $0.1 \mathrm{mg} \cdot \mathrm{L}^{-1} \mathrm{GA}_{3}$ alone or $0.1 \mathrm{mg} \cdot \mathrm{L}^{-1}$ BAP combined with $0.2 \mathrm{mg} \cdot \mathrm{L}^{-1} \mathrm{GA}_{3}$ were most effective in producing new axillary shoots $1 \mathrm{~cm}$ or larger; shoot yield differences were statistically significant $(P=0.05)$ between these treatments and media without BAP and $\mathrm{GA}_{3}$ (Figs. $1 \mathrm{C}$ and $3 \mathrm{~A}$ ). Media with BAP alone caused multiplication, but shoots were often less than $1 \mathrm{~cm}$. In this experiment, nodal segments tended to form more shoots than tips or bases. Based on shoot appearance and yields, further experiments focused on combinations of $0.1 \mathrm{mg} \cdot \mathrm{L}^{-1}$ BAP and low concentrations of $\mathrm{GA}_{3}$.

Results from the third shoot multiplication experiment continued to support the efficacy of BAP and $\mathrm{GA}_{3}$ mixtures (Fig. 3B). Basal shoot clusters tended to produce more shoots when $0.1 \mathrm{mg} \cdot \mathrm{L}^{-1} \mathrm{BAP}$ was combined with 0.1 to $0.2 \mathrm{mg} \cdot \mathrm{L}^{-1} \mathrm{GA}_{3}$. When comparing production of new shoots from tips, nodal segments, and basal segments with the output of basal clusters, the clusters produced more new shoots than the segmented method, and differences were statistically significant (Fig. 3B). Many shoot cultures, in culture for $\approx 1$ year, continued to show sustainable shoot multiplication when transferred every 6 to 8 weeks.

\section{Georgia aster root induction in vitro and acclimation to soil}

Roots began to appear in vitro after $7 \mathrm{~d}$ on shoots exposed to medium containing NAA vs. $10 \mathrm{~d}$ for growth regulator-free medium, but ending results from these two treatments were similar (Table 3; Fig. 1D). Root appearance 
Table 4. Symphyotrichum georgianum germination after 4 weeks for control and cryopreserved seed equilibrated at $12 \%$ relative humidity for 0 to 4 weeks. $^{2}$

\begin{tabular}{|c|c|c|c|c|c|c|c|}
\hline \multirow[b]{4}{*}{ Drying time } & \multicolumn{6}{|c|}{ Seed lot } & \multirow{4}{*}{$\begin{array}{l}\text { Germination } \\
\text { percent for } \\
\text { combined lots }\end{array}$} \\
\hline & \multicolumn{2}{|r|}{ SC5 } & \multicolumn{2}{|c|}{ SC7 } & \multicolumn{2}{|r|}{ SC8 } & \\
\hline & & Germination & \multicolumn{2}{|r|}{ Germ } & \multicolumn{2}{|r|}{ Germ } & \\
\hline & $\mathrm{NC}$ seed & (\%) & $\mathrm{NC}$ seed & $(\%)$ & $\mathrm{NC}$ seed & (\%) & \\
\hline \multicolumn{8}{|l|}{ No drying } \\
\hline Control & 11 & 27 & 10 & 30 & 15 & 73 & 47 \\
\hline Cryopreserved & 13 & 38 & 10 & 50 & 12 & 83 & 57 \\
\hline \multicolumn{8}{|l|}{ One-week drying } \\
\hline Control & 3 & 0 & 8 & 38 & 14 & 64 & 48 \\
\hline Cryopreserved & 11 & 9 & 8 & 63 & 9 & 78 & 46 \\
\hline \multicolumn{8}{|l|}{ Two-week drying } \\
\hline Control & 11 & 27 & 6 & 50 & 14 & 64 & 48 \\
\hline Cryopreserved & 10 & 30 & 6 & 83 & 13 & 62 & 55 \\
\hline \multicolumn{8}{|l|}{ Three-week drying } \\
\hline Control & 11 & 9 & 9 & 67 & 13 & 92 & 58 \\
\hline Cryopreserved & 14 & 0 & 7 & 57 & 14 & 79 & 43 \\
\hline \multicolumn{8}{|l|}{ Four-week drying } \\
\hline Control & 14 & 7 & 10 & 20 & 15 & 67 & 33 \\
\hline Cryopreserved & 14 & 14 & 10 & 30 & 15 & 93 & 49 \\
\hline
\end{tabular}

${ }^{\mathrm{z} I n i t i a l}$ numbers of seeds for each treatment were 15 for SC5, 10 for SC8, and 15 for SC8. Contaminated seeds were discarded and germination percentages are based on non-contaminated (NC) seed. Before equilibration at $12 \%$ relative humidity or cryostorage, seed water contents were measured as follows: SC5 to $12.9 \%, \mathrm{SC} 7$ to $11.2 \%$, and $\mathrm{SC} 8$ to $7.3 \%$.

times and survival after planting did not differ in shoots grown on multiplication medium vs. those grown in multiplication medium followed by a growth regulator-free exposure. Evaluations at 2 weeks or 1 month after planting showed that nearly all shoots survived and at 1 month many were growing (Table 3). After 1 month, a few shoots were carefully removed from the soil to examine root growth; all showed abundant roots (Fig. 1E). All treatments produced high survival percentages that did not differ significantly between multiplication and rooting treatments (Table 3).

\section{Georgia aster seed cryopreservation in liquid nitrogen}

S. georgianum seed water contents were measured as follows: SC5 to $12.9 \%$, SC7 to $11.2 \%$, and SC8 to $7.3 \%$. The numbers of germinating seeds for each treatment and seed source can be found in Table 4. Germination percentages are based on germination of non-contaminated seeds. Across all seed sources and drying treatments, germination averaged $42.7 \%$ for seed without LN treatment and $46.7 \%$ germination for cryopreserved seed. An analysis of variance showed no statistical difference between groups stored at room temperature or in $\mathrm{LN}(\mathrm{df}=1, \mathrm{~F}$-ratio $=$ $0.62, P=0.43$ ). Germination also did not differ significantly for seeds not dried or dried for 1 to 4 weeks at $12 \%$ relative humidity. However, all three seed lots differed significantly from each other in germination with averages of $14 \%, 44 \%$, and $76 \%$ for SC 5, SC 7 , and SC 8 , respectively. Seeds from SC5 consistently showed lower germination percentages than those from SC7 and SC8. Seeds from lots SC7 and SC8 had a cylindrical appearance, whereas seeds from lot SC5 were flatter and wider.

\section{Discussion}

Micropropagation and cryopreservation procedures are reported for the first time for
$S$. georgianum. Sustainable shoot cultures were developed using a combination of half-strength MS salts, BAP, and gibberellic acid. Shoot proliferation rates from tips, nodal segments, and bases yielded a combined average of 18 new shoots that could be easily established in the greenhouse. BAP improved budbreak and shoot multiplication, whereas $\mathrm{GA}_{3}$ elongated shoots to a size suitable for rooting. Seed germination was highest with fresh seeds and declined rapidly for seeds stored at room temperature or $4{ }^{\circ} \mathrm{C}$. Germination percentages before and after cryopreservation were similar and may provide a long-term safekeeping method for seeds.

BAP and $\mathrm{GA}_{3}$ combinations have produced shoots for other Asteraceae species: Wedelia calendulacea, Helianthus annuus L., Eclipta alba (L.) Hassk, and Sericocarpus rigidus Lindl. (Dhaka and Kothari, 2002, 2005; Emmanuel et al., 2000; Frey et al., 2007). Georgia aster grows in soils with $\mathrm{pH}$ varying from 4.4 to 6.8 (USFWS, 2010). The half-strength MS medium we used was adjusted to $\mathrm{pH}$ 5.7. Populations growing under $\mathrm{pH}$ extremes may benefit in vitro from medium $\mathrm{pH}$ adjustments to better mimic their natural environments (Van Winkle and Pullman, 2003).

All rooting treatments including in vitro rooting in growth regulator-free or NAAcontaining medium or direct planting into greenhouse soil after rooting powder treatment resulted in high plant rooting and survival. Thus, shoots could be planted directly in greenhouse soil without an in vitro rooting treatment, which saves labor, in vitro materials, and time.

A micropropagation system similar to what we have developed for Georgia aster is helping conserve $S$. rigidus (White-top aster) (Frey et al., 2007). S. rigidus is a perennial species native to low-elevation grasslands of the Pacific Northwest that has many similarities with Georgia aster and is also threatened with extinction. Studies with this self-incompatible species concluded that destruction of habitat resulting from fire suppression and competition from exotic and native vegetation are the major reasons for decline (Clampitt, 1987; Frey et al., 2007).

Our study suggests Georgia aster seed viability declines over 1 to 2 years. Seed kept at room temperature lost viability after 1 year. Seed stored at $4{ }^{\circ} \mathrm{C}$ for 2 years showed a slower rate of loss in viability. When Barton (1939) evaluated aster seeds stored at $6.7 \%$ or higher water content at room temperature, germination declined to nearly $0 \%$ within 24 months. Aster seeds appear to have short seed longevity of 1 to 2 years, even under ideal storage conditions (Hill Gardens of Maine, 2011). Further study needs to determine Georgia aster seed longevity times.

With recent evidence that seed longevity in conventional seed banks at $-20^{\circ} \mathrm{C}$ is not as long as hoped (Li and Pritchard, 2009), it becomes increasingly important to evaluate other options for conservation of rare and endangered species. The family Asteraceae has been estimated to have the greatest number (2553) of endangered and threatened species (Pence, 2010). Successful seed cryopreservation using direct immersion or slow cooling followed by rapid thawing has been demonstrated for several commercial and endangered species in Asteraceae including Callistephus chinensis (L) Nees cv. Grego Mix, Carthamus tinctoris L. 'PI 259996', Catharanthus roseus (L) G. Don cv. Little Delicata, Centaurea hyssopifolia (Vahl), Chrysanthemum coccincum Willd. cv. Robinson's Single Mix, Dahlia pinnata Cav. cv. Early Bird, Dimorphotheca sinata D.C. cv. Glistening White, Gaillardia × grandifolora Van Houtte cv. Monarch Strain, Onopordum nervosum Boiss, Onopordum acanthium L., and Helianthus annuus L. (Gonzalez-Benito et al., 1998, 2001; Stanwood, 1985; Vertucci, 1989). In general, the optimum moisture content for seed cryopreservation varies from $7 \%$ to $14 \%$, depending on species and seed lipid content (Pritchard, 2007). In our experiments, field-collected seeds ranged in water content from $7.3 \%$ to $21.9 \%$. Extra drying did not improve survival after cryostorage, and $43 \%$ of the control (not frozen) seeds germinated when dried for 0 to 4 weeks at $12 \%$ relative humidity compared with $47 \%$ that germinated after immersion in LN.

The threatened status of Georgia aster may result from three negative factors occurring simultaneously to reduce existing populations and prevent establishment of new populations. Habitat loss from fire suppression and resulting competition from native and non-native species are removing choice environments for asexual spread and seedling recruitment. Reduction in seed set or germination further reduces the number and size of populations that in turn produce fewer seeds. In addition, short-term seed viability may limit establishment and maintenance of new and existing populations. Technology to multiply plants from the more threatened populations coupled with long-term seed banking in 
LN is likely to help conserve biodiversity for the species.

Many plant species are becoming rare in their natural environments as a result of loss of habitat, overcollection, or disease. Tissue culture laboratories are becoming major resources for propagation and safekeeping of rare and endangered plants (Sarasan et al., 2006). Methods are presented here for longterm Georgia aster seed storage at ultralow temperatures, in vitro germination, micropropagation, and plant establishment in soil. The procedures developed provide valuable tools to preserve germplasm and genetic diversity in $S$. georgianum and will likely assist in the conservation of these beautiful and valuable plants. We have additional experiments ongoing to determine seed viability after long-term storage at room temperature, $4{ }^{\circ} \mathrm{C},-20{ }^{\circ} \mathrm{C}$, and in LN. Our current results suggest that cryopreservation technology should be implemented immediately in conservation efforts to protect this threatened species.

\section{Literature Cited}

Barton, L.V. 1939. Storage of some flower seeds. Boyce Thompson Inst. Contrib. 10:399-427.

Chafin, L. 2007. Field guide to the rare plants of Georgia. University of Georgia Press, Athens, GA.

Clampitt, C.A. 1987. Reproductive biology of Aster curtus (Asteraceae), a Pacific Northwest endemic. Amer. J. Bot. 74:941-946.

Dhaka, N. and S.L. Kothari. 2002. Phenylacetic acid improves bud elongation and in vitro plant regeneration efficiency in Helianthus annuus L. Plant Cell Rpt. 21:29-34.

Dhaka, N. and S.L. Kothari. 2005. Micropropagation of Eclipta alba (L.) Haask-An important medicinal plant. In Vitro Cell. Dev. Biol. Plant 41:658-661.

Emmanuel, S., S. Ignacimuthu, and K. Kathiravan. 2000. Micropropagation of Wedelia calendulacea Less., a medicinal plant. Phytomorphology 50:195-200.
Englemann, F. 2011. Use of biotechnologies for the conservation of plant diversity. In Vitro Cell. Dev. Biol. Plant 47:5-16.

Fay, M.F. 1992. Conservation of rare and endangered plants using in vitro methods. In Vitro Cell. Dev. Biol. Plant 28:1-4.

Federal Register. 2009. Symphyotrichum georgianum (Georgia aster). Federal Register 74 $57862<$ http://www.fws.gov/policy/library/2009/ E9-26841.html>.

Frey, B., C. Kempler, and D.L. Ehret. 2007. Micropropagation of White-top Aster, Sericocarpus rigidus, a threatened species from the Garry Oak Ecosystem in British Columbia. Can. Field-Naturalist 121:40-45.

Georgia Department of Natural Resources Wildlife Resources Division. 2008. <http:// www.georgiawildlife.com/sites/default/files/ uploads/wildlife/nongame/pdf/accounts/plants/ symphyotrichum_georgianum.pdf $>$.

Gonzalez-Benito, M.E., F. Fernandez-Llorente, and F. Perez-Garcia. 1998. Interaction between cryopreservation, rewarming rate and seed humidification on the germination of two Spanish endemic species. Ann. Bot. (Lond.) 82:683-686.

Gonzalez-Benito, M.E. and F. Perez-Garcia. 2001 Cryopreservation of lipid-rich seeds: Effects of moisture content and cooling rate on germination. Cryo Lett. 22:135-140.

Hill Gardens of Maine. 2011. Longevity of seeds in ideal storage. $<\mathrm{http}: / / \mathrm{www}$.hillgardens.com/seed_ longevity.htm>.

Li, D.-Z. and H.W. Pritchard. 2009. The science and economics of ex situ plant conservation. Trends Plant Sci. 14:614-621.

Murashige, T. and F. Skoog. 1962. A revised medium for rapid growth and bioassays with tobacco tissue cultures. Physiol. Plant. 15:473497.

Pence, V.C. 1991. Cryopreservation of seeds of Ohio native plants and related species. Seed Sci. Technol. 19:235-251.

Pence, V.C. 2010. The possibilities and challenges of in vitro methods for plant conservation. Kew Bull. 65:539-547.

Pritchard, H.W. 2007. Cryopreservation of desiccationtolerant seeds, p. 185-201. In: Day, J.G. and G.N. Stacey (eds.). Methods in molecular biology, Vol. 368: Cryopreservation and freeze-drying protocols. $2^{\text {nd }}$ Ed. Humana Press Inc., Totowa, $\mathrm{NJ}$

Pullman, G.S., R. Chopra, and K.-M. Chase. 2006 Loblolly pine (Pinus taeda L.) somatic embryogenesis: Improvements in embryogenic tissue initiation by supplementation of medium with organic acids, Vitamins $B_{12}$, and E. Plant Sci. 170:648-658.

Pullman, G.S., S. Johnson, S. Van Tassel, and Y. Zhang. 2005. Somatic embryogenesis in loblolly pine (Pinus taeda L.) and Douglas fir [Pseudotsuga menziesii (Mirb) Franco]: Improving culture initiation with MES $\mathrm{pH}$ buffer, biotin, and folic acid. Plant Cell Tissue Organ Cult. 80:91-103.

Reed, B.M., V. Sarasan, M. Kane, E. Bunn, and V.C. Pence. 2011. Biodiversity conservation and conservation biotechnology tools. In Vitro Cell. Dev. Biol. Plant 47:1-4.

Sarasan, V., C. Ryan, M.M. Ramsay, C. Atherton, M. McMichen, G. Prendergast, and J.K. Rowntree. 2006. Conservation in vitro of threatened plants-Progress in the past decade. In Vitro Cell. Dev. Biol. Plant 42:206-214.

Stanwood, C.S. 1985. Cryopreservation of seed germplasm for genetic conservation, p. 200 226. In: Kartha, K.K. (ed.). Cryopreservation of plant cells and organs. CRC Press Inc., Boca Raton, FL.

USFWS. 2010. Species assessment and listing priority assignment form-Symphyotrichum georgianum. $<\mathrm{http}: / / \mathrm{www}$. fws.gov/ecos/ajax/ docs/candforms_pdf/r4/Q2Z5_P01.pdf>.

Van Winkle, S.C. and G.S. Pullman. 2003. The combined impact of $\mathrm{pH}$ and activated carbon on the elemental composition of plant tissue culture media. Plant Cell Rpt. 22:303-311

Vertucci, C.W. 1989. Effects of cooling rate on seeds exposed to liquid nitrogen temperatures. Plant Physiol. 90:1478-1485.

Walls, M. 2009. Seed storage guidelines for California native plant species. <http://www.rsabg. org/documents/horticulture/Seed\%20Collecting\% 20 and $\% 20$ Storage $\% 20$ Guidelines.pdf $\$$.

Weakley, A.S. 2011. Flora of the southern and midatlantic states. UNC Herbarium, North Carolina Botanical Garden, University of North Carolina at Chapel Hill. < http://www.herbarium. unc.edu/flora.htm>. 